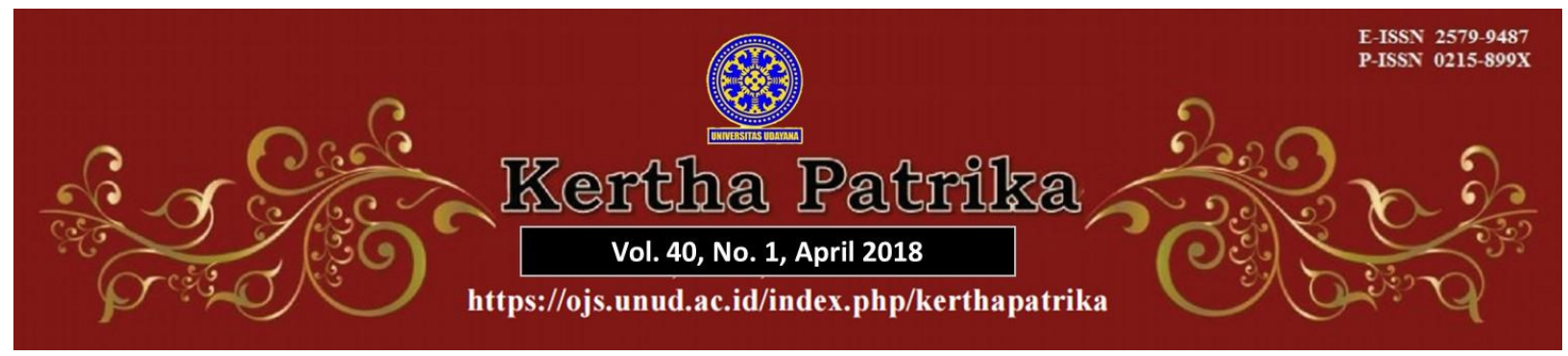

\title{
EFEKTIVITAS TATA HUTAN DI KAWASAN HUTAN LINDUNG GUNUNG SERAYA DALAM UPAYA MENGAKOMODIR KEPENTINGAN RELIGI
}

\author{
Oleh : \\ Dikdik Adiarsa ${ }^{1}$ \\ Dinas Kehutanan Provinsi Bali, UPT Kesatuan Pengelolaan Hutan Bali Timur
}

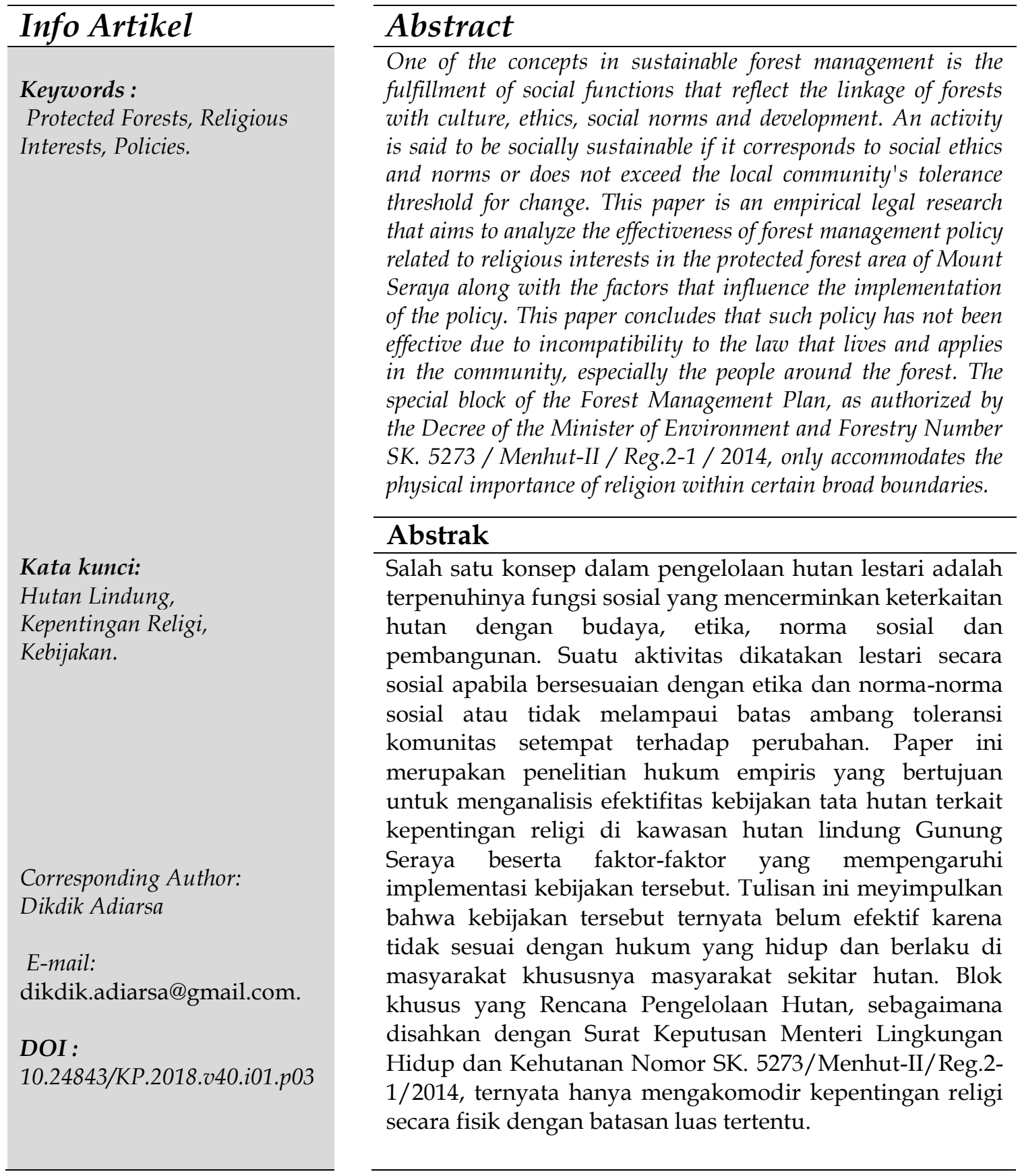

${ }^{1}$ Dikdik Adiarsa adalah staff pada Dinas Kehutanan Provinsi Bali, UPT KPH Bali Timur. Korespondensi dengan penulis melalui email : dikdik.adiarsa@gmail.com. 


\section{Pendahuluan}

Ketentuan Pasal 1 angka 2 Undang-Undang Republik Indonesia Nomor 41 Tahun 1999 tentang Kehutanan (selanjutnya disebut Undang-Undang Kehutanan) menjelaskan bahwa hutan adalah suatu kesatuan ekosistem berupa hamparan lahan berisi sumber daya alam hayati yang didominasi pepohonan dalam persekutuan alam lingkungannya, yang satu dengan lainnya tidak dapat dipisahkan. Berdasarkan definisi tersebut maka hutan wajib dikelola secara terencana dan terpadu agar memberikan manfaat bagi lingkungan dan kehidupan manusia. Oleh karena itu dalam merencanakan dan melaksanakan pengelolaan hutan, harus dilakukan secara holistik dan terintegrasi.

Dalam pandangan Hindu, seperti yang tercantum dalam lontar Bhuwana Kosa VIII, 2-3 sebagaimana dikutip oleh I Ketut Wiana,2 dikatakan bahwa hutan sebagai sumber penyucian alam dimana patra (tumbuh-tumbuhan) dan pertiwi (tanah) merupakan pelebur dari segala hal yang kotor di dunia ini. Pustaka suci Rgveda III.51.5 misalnya menyebutkan: "Indraa ya dyaava osadhir uta aapah. Rayim raksanti jiyaro vanani" yang artinya tanpa terlindungi sumber-sumber alam tersebut manusia tidak akan pernah mendapatkan kehidupan yang aman damai dan sejahtera. Di bumi ini ada tiga Ratna Permata yaitu air, tumbuh-tumbuhan bahan makanan dan obat obatan. Air akan terpelihara apabila ada kawasan hutan yang terpelihara dan terlindungi dengan sebaik-baiknya. Dengan tersimpannya air melalui hutan yang lestari maka tumbuhtumbuhan, bahan makanan dan obat-obatan dapat dikembangkan dengan sebaikbaiknya.

Masalah utama dalam pengelolaan hutan sesungguhnya tidak hanya terletak pada aspek manajemen, teknik budidaya atau teknologi tetapi juga sosial budaya yang secara terus menerus berproses secara dinamik dan inovatif. Masalah sosial budaya tersebut berhubungan dengan status kawasan hutan, batas kawasan hutan dan batasbatas kewenangan antara masyarakat lokal dengan aparat pemerintah. Perubahanperubahan nilai sumber daya lahan dan hutanpun turut melahirkan kompleksitas kepentingan antara pihak dan mendorong lahirnya negosiasi dan konsensus baru dalam pengelolaan hutan.

Bali mempunyai tiga elemen utama yang merupakan ciri khas yang sangat tipikal dibandingkan dengan daerah lainnya, yaitu alam, masyarakat (kebudayaan) dan agamanya. Dekatnya agama dan adat sebagaimana dituangkan dalam sejumlah peraturan daerah dan keputusan Parisadha Hindu Dharma Indonesia (PHDI) menjadi bukti bagaimana masyarakat Bali ditata dalam dalam ruang lingkup agama dan adat. Dua kompilasi regulasi seperti Peraturan Daerah Provinsi Bali Nomor 16 Tahun 2009 tentang Rencana Tata Ruang Wilayah Provinsi Bali dan Keputusan Bhisama PHDI Pusat Nomor 11/Kep./1/PHDI/1994 tentang Bhisama Kesucian Pura, menggambarkan bagaimana pertalian erat antara kepercayaan umat Hindu, landasan

\footnotetext{
2 I Ketut Wiana. (2014) "Mulianya Pahala Menjaga Kelestarian Hutan", disampaikan pada Dharma Wacana tentang upaya pelestarian hutan menurut agama Hindu yang diselenggarakan oleh Dinas Kehutanan Provinsi Bali di Desa Ban, Kecamatan Kubu, Kabupaten Karangasem, pada 24 Juni 2010.
} 
adat dan regulasi pemerintah menata kehidupan lingkungan di Pulau Bali. Bertolak dari tiga landasan utama yaitu agama, adat dan pemerintah maka terkait urusan pengelolaan lingkungan khususnya hutan di Pulau Bali akan lebih berkelanjutan (sustainable) dibandingkan dengan daerah-daerah lainnya, sebab dua pilar aturan sangat mendukung pelestarian sumber daya alam yang dipercayai oleh umat Hindu bernilai religius. ${ }^{3}$

Masyarakat di sekitar kawasan hutan Gunung Seraya Kabupaten Karangasem Bali (RTK 9) memiliki sistem dan struktur masyarakat yang homogen. Hal tersebut dapat dilihat dari kesamaan etnis yaitu etnis Bali yang beragama Hindu. Sistem garis keturunan dan hubungan kekerabatan penduduk masyarakat di sekitar hutan masih berpegang pada pinsip patrilineal (purusa) yang sangat dipengaruhi oleh sistem keluarga luar patrilineal yang mereka sebut dadia. Penduduk disekitar kawasan hutan terbagi dalam pelapisan sosial yang dipengaruhi oleh sistem nilai, utama, madya dan nista. Kasta utama atau tertinggi adalah golongan Brahmana, kasta madya adalah golongan Ksatrya, dan kasta nista adalah golongan Waisya. Selain itu masih ada golongan yang dianggap paling rendah atau tidak berkasta yaitu golongan Sudra, sering juga disebut jaba wangsa (tidak berkasta). Dari kekuatan sosial kekerabatannya dapat pula dibedakan atas klen pande, pasek, bujangga dan sebagainya.

Kehidupan sosial budaya sehari-hari khususnya penduduk di sekitar hutan hampir semuanya dipengaruhi oleh keyakinan/kepercayaan kepada agama Hindu yang dianut, oleh karena itu adat istiadat dan kebudayaan penduduk tidak dapat dilepas dari pengaruh sistem religi agama Hindu. Budaya Bali merupakan cerminan adat istiadat masyarakat Bali yang dijiwai agama Hindu. Sejak peradaban Bali dipengaruhi oleh Hindu sekitar tahun 835, di dalam hutan telah dibangun pemujaan roh-roh leluhur, kemudian lebih maju lagi dibangunlah Pura di lereng dan puncak-puncak gunung serta di tengah hutan belantara yang sepi dan hening, ${ }^{4}$ yang salah satunya di kawasan hutan lindung Gunung Seraya.

Kawasan hutan Gunung Seraya (RTK 9) merupakan salah satu kawasan hutan di Kesatuan Pengelolaan Hutan (KPH) Bali Timur yang mempunyai fungsi pokok sebagai hutan lindung. Pasal 1 angka 8 Undang-Undang Kehutanan menjelaskan bahwa hutan lindung adalah kawasan hutan yang mempunyai fungsi pokok sebagai perlindungan sistem penyangga kehidupan untuk mengatur tata air, mencegah banjir, mengendalikan erosi, mencegah intrusi air laut, dan memelihara kesuburan tanah.

Gunung Seraya merupakan salah satu kawasan suci, dimana pada kawasan tersebut terdapat Kahyangan (Pura) atau Tempat Suci. Sebab di tempet-tempat itu orang suci dan umat Hindu mendapat pikiran-pikiran suci (wahyu), yang dalam penetapannya ditentukan oleh Pemerintah Daerah dengan mendapatkan pertimbangan unsur-unsur pendukung budaya lokal seperti lembaga adat, subak dan PHDI. Kawasan tempat suci adalah kawasan yang berada pada radius kesucian pura dengan jiwa yang termuat dalam bishama (fatwa) dari PHDI tentang kesucian Pura. Dari segi formulasi atau konseptualisasi "tempat suci adalah suatu tempat yang berwujud bangunan suci umat

\footnotetext{
${ }^{3}$ Herman Hidayat, dkk. (2011). Politik Ekologi : Pengelolaan Taman Nasional Era Otda. LIPI Press dan Yayasan Pustaka Obor Indonesia. Jakarta, h. 108.

${ }^{4}$ Dinas Kehutanan. (2009). Hutan dan Kehutanan Provinsi Bali Edisi V. Dinas Kehutanan Provinsi Bali. Denpasar, h. 12.
} 
Hindu atau "Pura/Kahyangan": yang terdiri dari "Kahyangan Tiga", "Dang Kahyangan" dan "Sad Kahyangan".

Salah satu konsep dalam pengelolaan hutan lestari adalah terpenuhinya fungsi sosial yang mencerminkan keterkaitan hutan dengan budaya, etika, norma sosial dan pembangunan. Suatu aktivitas dikatakan lestari secara sosial apabila bersesuaian dengan etika dan norma-norma sosial atau tidak melampaui batas ambang toleransi komunitas setempat terhadap perubahan.

Dalam rangka memenuhi fungsi sosial dari keberadaan hutan lindung Gunung Seraya, di dalam Rencana Pengelolaan Hutan yang disusun oleh Kepala KPH yang disahkan dengan Surat Keputusan Menteri Lingkungan Hidup dan Kehutanan Nomor SK. 5273/Menhut-II/Reg.2-1/2014 Tentang Rencana Pengelolaan Hutan Jangka Panjang KPHL Model Bali Timur Periode Tahun 2014-2023, kawasan hutan lindung Gunung Seraya (RTK 9) yang digunakan untuk kegiatan religi yang berupa adanya bangunan suci (Pura) ditetapkan menjadi blok khusus yang dilakukan tanpa mengubah fungsi pokok kawasan hutan dengan mempertimbangkan batasan luas dan kelestarian lingkungan.

Kebijakan tata kelola hutan yang telah ditetapkan, merupakan "trade off" antara dua kepentingan besar. Di satu sisi, Gunung Seraya merupakan kawasan hutan lindung yang mempunyai fungsi pokok sebagai perlindungan sistem penyangga kehidupan untuk mengatur tata air, mencegah banjir, mengendalikan erosi, mencegah intrusi air laut, dan memelihara kesuburan tanah, di sisi lain kepentingan religi merupakan salah satu kepentingan strategis yang tidak dapat dielakan dan menjadi salah satu kegiatan prioritas karena mempunyai pengaruh yang sangat penting terhadap bidang sosial dan budaya masyarakat.

Peruntukan kawasan hutan untuk fungsi tertentu dalam rencana tata ruang seharusnya diikuti oleh pemanfaatan atau penggunaan lahan yang mengarah pada tujuan dari rencana tata ruang itu sendiri. Tata ruang merupakan landasan sekaligus sasaran pembangunan wilayah. Perkembangan wilayah menjadi salah satu indikator keberhasilan pembangunan. Perkembangan wilayah pada kawasan yang tidak sesuai dengan tujuan peruntukannya justru menjadi ancaman terhadap keberhasilan pembangunan kawasan yang fungsi dan peruntukannya telah ditetapkan dalam rencana tata ruang. ${ }^{5}$ Dalam konteks pengelolaan sumber daya alam yang lebih luas, beberapa penelitian menyatakan bahwa fenomena akses terbuka (open access) terhadap sumber daya alam merupakan salah satu penyebab banyaknya kegagalan pengelolaan sumber daya alam. ${ }^{6}$

Berdasarkan uraian-uraian diatas, dengan demikian penulis tertarik mengadakan penelitian dan menuangkannya dalam penulisan hukum dengan judul: "Efektivitas

\footnotetext{
${ }^{5}$ Ariyadi Agustiono dkk. (2014). Kajian Perubahan Penggunaan Lahan Untuk Arahan Penataan Pola Ruang Kawasan Hutan Produksi Gedong Wani Provinsi Lampung. Majalah Ilmiah Globë, 16(1), h. 59-67.

6 Alan Purbawiyatna, dkk. (2011). Analisis Kelestarian Pengelolaan Hutan Rakyat di Kawasan Berfungsi Lindung. Jurnal Pengelolaan Sumber Daya Alam dan Lingkungan. 2(1), h. 84-92.
} 
Tata Hutan Di Kawasan Hutan Lindung Gunung Seraya Dalam Upaya Mengakomodir Kepentingan Religi."

Dengan latar belakang tersebut diatas, adapun permasalahan yang dapat dikaji dalam artikel ini, yaitu:

1. Apakah kebijakan tata hutan terkait kepentingan religi di kawasan hutan lindung Gunung Seraya dapat berlaku efektif?

2. Faktor-faktor apakah yang mempengaruhi efektifitas implementasi kebijakan tata hutan di Kawasan Hutan Lindung Gunung Seraya?

\section{Metode Penelitian}

Jenis penelitian ini adalah penelitian hukum empiris. Penelitian hukum empiris merupakan penelitian tentang fakta-fakta sosial masyarakat atau fakta-fakta berlakunya hukum di masyarakat. ${ }^{7}$ Dalam penelitian ini, sifat penelitian yang digunakan deskriptif analisis yaitu dapat menggambarkan secara tepat, rinci, sistematis dan menyeluruh serta menggunakan cara dengan menganalisis data yang diperoleh yang berkaitan dengan permasalahan sehingga mendapatkan gambaran yang jelas. ${ }^{8}$

\section{Hasil dan Pembahasan}

\subsection{Tata Hutan dan Rencana Pengelolaan Hutan di Kawasan Hutan Lindung Gunung Seraya.}

Konsep pengelolaan hutan lestari didasarkan atas terpenuhinya kelestarian tiga fungsi utama hutan, yaitu: 9

1. Fungsi Ekologis/Lingkungan yaitu ekosistem hutan harus mendukung kehidupan organisme yang sehat, tetap mempertahankan produktivitas, adaptabilitas dan kemampuannya untuk pulih kembali.

2. Fungsi Sosial yaitu mencerminkan keterkaitan hutan dengan budaya, etika, norma sosial dan pembangunan. Suatu aktivitas dikatakan lestari secara sosial apabila bersesuaian dengan etika dan norma-norma sosial atau tidak melampaui batas ambang toleransi komunitas setempat terhadap perubahan.

3. Fungsi Ekonomis yaitu menunjukkan bahwa manfaat dari hutan melebihi biaya yang dikeluarkan oleh unit manajemen dan modal yang ekuivalen dapat diinvestasikan dari satu generasi ke generasi berikutnya.

Dalam rangka memenuhi fungsi sosial dari keberadaan hutan lindung Gunung Seraya, di dalam Rencana Pengelolaan Hutan yang disusun oleh Kepala KPH yang disahkan dengan Surat Keputusan Menteri Lingkungan Hidup dan Kehutanan Nomor SK. 5273/Menhut-II/Reg.2-1/2014 Tentang Rencana Pengelolaan Hutan Jangka Panjang KPHL Model Bali Timur Periode Tahun 2014-2023, kawasan hutan lindung Gunung Seraya (RTK 9) yang digunakan untuk kegiatan religi yang berupa adanya bangunan suci (Pura) ditetapkan menjadi blok khusus yang dilakukan tanpa mengubah fungsi

\footnotetext{
7 Bahder Johan Nasution. (2008). Metode Penelitian Ilmu Hukum. Mandar Maju. Bandung, h. 135.

${ }^{8}$ Ni Made Anggia Paramesthi Fajar. (2015). Pelaksanaan Peraturan Daerah Provinsi Bali No 5 Tahun 2008 Tentang Pramuwisata di Kabupaten Badung. Jurnal Magister Hukum Udayana (Udayana Master Law Journal). 4(2), h. 344.

9 Bambang Eko Supriyadi. (2013). Hukum Agraria Kehutanan, Aspek Hukum Pertanahan dalam Pengelolaan Hutan Negara. Raja Grafindo Persada. Jakarta, h. 1.
} 
pokok kawasan hutan dengan mempertimbangkan batasan luas dan kelestarian lingkungan.

Tabel 1.1.

Blok Khusus dalam Kawasan Hutan Lindung

Gunung Seraya (RTK 9)

\begin{tabular}{|c|c|c|c|c|}
\hline No. & Nama Pura & RPH & $\begin{array}{l}\text { Luas } \\
\text { (M2) }\end{array}$ & Status Pura \\
\hline 1 & Lempuyang Luhur & \multirow{9}{*}{ Abang } & 1042 & Sad Kayangan \\
\hline 2 & Pasar Agung & & 400 & Dang Kayangan \\
\hline 3 & Pedukuhan & & 391 & Dadia \\
\hline 4 & Telaga Mas & & 540 & Dang Kayangan \\
\hline 5 & $\begin{array}{l}\text { Pemerajan Agung Tanah } \\
\text { Aji }\end{array}$ & & 275 & Dang Kayangan \\
\hline 6 & Penataran Karang Kasmadi & & 100 & Dang Kayangan \\
\hline 7 & Lempuyang Madya & & 800 & Dang Kayangan \\
\hline 8 & Puncak Bisbis & & 207 & Dang Kayangan \\
\hline 9 & Telaga Sawang & & 260 & Dang Kayangan \\
\hline 10 & Maspahit & \multirow{3}{*}{ Karangasem } & 450 & Dang Kayangan \\
\hline 11 & Maja Pahit & & 225 & Dang Kayangan \\
\hline 12 & Bale Angut & & 225 & Dang Kayangan \\
\hline & & JUMLAH & 4915 & \\
\hline
\end{tabular}

Sumber: Seksi Perencanaan dan Pemanfaatan, KPH. Bali Timur, RPHJP tahun 2014-2923.

Berdasarkan hasil wawancara dengan pihak UPT. KPH. Bali Timur, Made Warta dijelaskan bahwa kepentingan religi yang diakomodir dalam blok khusus merupakan kepentingan yang bersifat fisik, yaitu adanya bangunan suci Pura. Lebih lanjut dijelaskan kebijakan yang diambil terkait tata kelola hutan di kawasan hutan lindung Gunung Seraya, merupakan "trade off" antara dua kepentingan besar. Di satu sisi, Gunung Seraya merupakan kawasan hutan lindung yang mempunyai fungsi pokok sebagai perlindungan sistem penyangga kehidupan untuk mengatur tata air, mencegah banjir, mengendalikan erosi, mencegah intrusi air laut, dan memelihara kesuburan tanah, di sisi lain kepentingan religi merupakan salah satu kepentingan strategis yang tidak dapat dielakan dan menjadi salah satu kegiatan prioritas karena mempunyai pengaruh yang sangat penting terhadap bidang sosial dan budaya masyarakat. Kebijakan yang ditetapkan juga dilakukan dengan mempertimbangkan batasan luas dan kelestarian lingkungan, hal ini perlu disadari mengingat rasio luas hutan di Provinsi Bali masih kurang dari yang diamanatkan oleh Undang-Undang Kehutanan yaitu 30\% dari luas daratan dengan kondisi relatif kurang baik, sehingga penggunaan kawasan hutan untuk kedepannya perlu dibatasi dan dilakukan secara selektif.

Kebijakan tata kelola hutan yang ditetapkan sebenarnya ditujukan untuk pihak KPH, yaitu sebagai acuan dalam pengelolaan hutan tetapi secara tidak langsung memang akan berakibat kepada masyarakat. Kebijakan ini bersifat manajerial, yaitu terkait tata ruang dalam kawasan hutan. Hal-hal terkait penegakan hukum tetap merujuk kepada peraturan perundang-undangan yang lebih tinggi. Aminuddin Ilmar mengemukakan bahwa tidak semua rencana pemerintah memiliki akibat hukum langsung bagi warga 
masyarakat. Sebagai bagian dari tindakan atau perbuatan hukum pemerintahan, maka rencana itu dapat disebut sebagai sebuah figur hukum yang memiliki relevansi dengan hukum. ${ }^{10}$

\subsection{Kepentingan Religi di Kawasan Hutan Lindung Gunung Seraya.}

Kehidupan sosial budaya sehari-hari khususnya masyarakat di sekitar kawasan hutan Gunung Seraya hampir semuanya dipengaruhi oleh keyakinan/kepercayaan kepada agama Hindu yang dianut, oleh karena itu adat istiadat dan kebudayaan penduduk tidak dapat dilepas dari pengaruh sistem religi agama Hindu. Budaya Bali merupakan cerminan adat istiadat masyarakat Bali yang dijiwai agama Hindu.

Berdasarkan data Seksi Pemolaan, Balai Pemantapan Kawasan Hutan Wilayah VIII, Bali Nusa Tenggara, dalam kegiatan identifikasi Enclave Pura di kelompok hutan Gunung Seraya (RTK 9) Hutan Tahun 2001 dan 2002, di Kawasan Hutan Lindung Gunung Seraya terdapat 12 lokasi penggunaan kawasan hutan yaitu penggunaan kawasan hutan untuk kepentingan religi berupa bangunan suci Pura. Data seperti tercantum dalam tabel 1.2.

Tabel 1.2.

Data Adanya Pura dalam Kawasan Hutan Lindung Gunung Seraya (RTK 9)

\begin{tabular}{|c|c|c|c|c|c|}
\hline No & Nama Pura & $\mathrm{RPH}$ & $\begin{array}{c}\text { Jml } \\
\text { Pengemong }\end{array}$ & $\begin{array}{l}\text { Luas } \\
\text { (M2) }\end{array}$ & Status Pura \\
\hline 1 & $\begin{array}{l}\text { Lempuyang } \\
\text { Luhur }\end{array}$ & \multirow{9}{*}{ Abang } & $156 \mathrm{KK}$ & 1042 & Sad Kayangan \\
\hline 2 & Pasar Agung & & $156 \mathrm{KK}$ & 400 & Dang Kayangan \\
\hline 3 & Pedukuhan & & $50 \mathrm{KK}$ & 391 & Dadia \\
\hline 4 & Telaga Mas & & $156 \mathrm{KK}$ & 540 & Dang Kayangan \\
\hline 5 & $\begin{array}{l}\text { Pemerajan } \\
\text { Agung Tanah } \\
\text { Aji }\end{array}$ & & $78 \mathrm{KK}$ & 275 & Dang Kayangan \\
\hline 6 & $\begin{array}{l}\text { Penataran } \\
\text { Karang } \\
\text { Kasmadi }\end{array}$ & & $36 \mathrm{KK}$ & 100 & Dang Kayangan \\
\hline 7 & $\begin{array}{l}\text { Lempuyang } \\
\text { Madya }\end{array}$ & & $36 \mathrm{KK}$ & 800 & Dang Kayangan \\
\hline 8 & Puncak Bisbis & & $36 \mathrm{KK}$ & 207 & Dang Kayangan \\
\hline 9 & Telaga Sawang & & $36 \mathrm{KK}$ & 260 & Dang Kayangan \\
\hline 10 & Maspahit & \multirow{3}{*}{ Karangasem } & $534 \mathrm{KK}$ & 450 & Dang Kayangan \\
\hline 11 & Maja Pahit & & $534 \mathrm{KK}$ & 225 & Dang Kayangan \\
\hline 12 & Bale Angut & & $534 \mathrm{KK}$ & 225 & Dang Kayangan \\
\hline \multicolumn{4}{|r|}{ JUMLAH } & 4915 & \\
\hline
\end{tabular}

Sumber: Seksi Pemolaan, Balai Pemantapan Kawasan Hutan Wilayah VIII Bali Nusa Tenggara

Berdasarkan wawancara dengan Kepala Desa Adat Purwayu, Bapak I Made Jati, menjelaskan bahwa keberadaan Tempat Suci dalam kawasan hutan Gunung Seraya diperkirakan sudah ada sejak Tahun Caka 13 (Tahun 91 Masehi) sebelum masa

10 Aminuddin Ilmar. (2014). Hukum Tata Pemerintahan. Prenada Media Group. Jakarta, h. 200. 
penjajahan Belanda dan jauh sebelum kawasan hutan Gunung Seraya ditetapkan oleh Pemerintah menjadi kawasan hutan lindung yang awalnya ditemukan berupa gegumuk kemudian oleh sesepuh dibuat bangunan (Pelinggih). Lebih lanjut dijelaskan, terkait kebijakan tata kelola hutan di kawasan hutan lindung Gunung Seraya, khususnya terkait penetapan kepentingan religi menjadi Blok Khusus dengan batasan luas tertentu, pihak Desa adat maupun Pengempon tidak mengetahui dan tidak dilibatkan.

Lebih lanjut dijelaskan bahwa para pengempon Pura tersebut merupakan penduduk asli wilayah sekitaran Gunung Seraya, jumlah Pengempon Pura Telaga Mas, Pura Pasar Agung dan Pura Lempuyang Luhur terdiri dari 156 Kepala Keluarga dengan anggota keluarga sebanyak 1.061 jiwa yang berasal dari warga Dusun Purwa Ayu, Desa Adat Purwa Ayu dan Desa Tista, sedangkan Pura Pedukuhan Pengemponnya dari warga Pasek Pedukuhan terdiri dari 50 Kepala Keluarga dengan anggota keluarga sebanyat 240 jiwa yang berasal dari Dusun purwa Ayu, Desa Adat purwa Ayu, Desa Tista. Jumlah Pengempon Pura Telaga Mas, Pura Pasar Agung dan Pura Lempuyang Luhur terdiri dari 156 Kepala Keluarga dengan anggota keluarga sebanyak 1.061 jiwa yang berasal dari warga Dusun Purwa Ayu, Desa Adat Purwa Ayu dan Desa Tista, sedangkan Pura Pedukuhan Pengemponnya dari warga Pasek Pedukuhan terdiri dari 50 Kepala Keluarga dengan anggota keluarga sebanyat 240 jiwa yang berasal dari Dusun purwa Ayu, Desa Adat purwa Ayu, Desa Tista.

Jarak dari tempat tinggal Pengempon ke masing-masing Pura, adalah sebagai berikut : ${ }^{11}$

1. Pura Telaga mas, antara $501-1.000$ meter sebanyak $50 \mathrm{KK}$, antara 1.001 - 2000 meter sebanyak 75 KK dan lebih dari 2000 meter sebanyak 31 KK.

2. Pura Pasar Agung, dari Pura Telaga Mas $\pm 2,75 \mathrm{Km}$

3. Pura Lempuyang Luhur, dari Pura Telaga Mas melalui Pura Pasar Agung dengan jarak $\pm 3,5 \mathrm{Km}$. Pura Pedukuhan, hampir sama dengan Pura Telaga Mas karena bersebelahan.

Berdasarkan wawancara dengan Bapak I Made Ginarta, salah satu pengempon Pura Lempuyang, dijelaskan bahwa jalan yang ada saat ini kondisinya tidak dapat menampung pemendek disaat upacara puncak yang diselenggarakan setiap 210 hari mengingat umat yang sembahyang dari berbagai daerah di seluruh Bali bahkan dari luar Daerah.

Menurut teori efektivitas hukum sebagaimana dikemukakan oleh Soerjono Sukanto, efektif adalah taraf sejauh mana suatu kelompok dapat mencapai tujuannya. Hukum dapat dikatakan efektif jika terdapat dampak hukum yang positif, pada saat itu hukum mencapai sasarannya dalam membimbing atau merubah perilaku manusia sehingga menjadi perilaku hukum. ${ }^{12}$ Efektif atau tidaknya hukum tertulis atau ketentuan perundang-undangan ditentukan oleh lima faktor. Kelima faktor ini secara integratif dan tersistem akan menentukan apakah sebuah aturan itu dapat efektif berlaku dimasyarakat atau tidak.

${ }^{11}$ Observasi langsung.

12 Soerjono Soekanto. (1988). Efektivitas Hukum Dan Penerapan Sanksi. CV. Ramadja Karya. Bandung, h. 80. (selanjutnya disingkat Soerjono Soekanto II). 
Menurut Teori sociological jurisprudence, hukum yang baik adalah hukum yang sesuai dengan hukum yang hidup di dalam masyarakat. Sesuai di sini berarti bahwa hukum itu mencerminkan nilai-nilai yang hidup di dalam masyarakat. ${ }^{13}$ Mazhab ini mengetengahkan tentang pentingnya Living Law-hukum yang hidup di dalam masyarakat. Dan kelahirannya menurut beberapa anggapan merupakan suatu sinthese dari thesenya, yaitu positivisme hukum dan antithesenya mazhab sejarah. Dengan demikian sociological jurisprudence beranggapan kepada pentingnya, baik akal maupun pengalaman. ${ }^{14}$ Kenyataan yang hidup dalam masyarakat sering disebut sebagai "living law and just law" yang merupakan "inner order" yang tercermin dalam kehidupan masyarakat. ${ }^{15}$ Sociological Jurisprudence pada kenyataannya lebih menekankan pada masalah evaluasi hukum, kedudukan hukum tertulis dan tidak tertulis, fungsi hukum sebagai rekayasa sosial, pembentukan hukum yang baik dan cara penerapan hukum. ${ }^{16}$

Berdasarkan uraian dari beberapa ahli hukum di atas, jika dikaitkan dengan kebijakan tata hutan di kawasan hutan lindung Gunung Seraya, idealnya kebijakan yang telah ditetapkan dapat ditaati oleh masyarakat dengan baik, sehingga pelaksanaan suatu aturan akan menjadi efektif.

Berdasarkan kenyataan yang terjadi dalam pelaksanaan kebijakan tata kelola hutan, terkait pengaturan kepentingan religi di kawasan hutan lindung Gunung Seraya, belum dapat dikatakan berlaku efektif. Seperti halnya pendapat Soerjono Soekanto yang menyatakan hukum dapat dikatakan efektif jika terdapat dampak hukum yang positif, pada saat itu hukum mencapai sasarannya dalam membingbing atau merubah perilaku manusia sehingga menjadi perilaku hukum. Secara umum Soerjono Soekanto menyatakan bahwa derajat efektivitas suatu hukum ditentukan dari taraf kepatuhan masyarakat terhadap hukum, termasuk oleh para penegak hukumnya, sehingga dikenal suatu asumsi bahwa taraf kepatuhan hukum yang tinggi merupakan suatu indicator berfungsinya suatu sistem hukum. Berfungsinya hukum merupakan pertanda bahwa hukum tersebut telah mencapai tujuan hukum, yaitu berusaha untuk mempertahankan dan menghubungi masyarakat dalam pergaulan hidup. ${ }^{17}$

Apabila dikaitkan dengan teori sociological jurisprudence, kebijakan tata hutan di kawasan hutan lindung Gunung Seraya khususnya terkait pengaturan penggunaan kawasan untuk kepentingan religi, juga belum bisa dikatakan sesuai dengan hukum yang hidup di dalam masyarakat. Hal ini berarti kebijakan tata kelola hutan yang ditetapkan belum mencerminkan nilai-nilai yang hidup di dalam masyarakat.

Agama Hindu dalam kitab sucinya yaitu Weda-weda telah menguraikan tentang apa yang disebut dengan Tempat-Tempat Suci dan Kawasan Suci, Gunung, Danau, Campuan (pertemuan sungai), Pantai, Laut dan sebagainya diyakini memiliki nilai-nilai kesucian. Oleh karena itu Pura dan tempat-tempat suci umumnya didirikan ditempat tersebut, karena ditempat tersebut orang-orang suci dan umat Hindu mendapatkan pikiran-pikiran suci (wahyu). Tempat-tempat suci tersebut telah menjadi pusat-pusat bersejarah yang melahirkan karya-karya besar dan abadi lewat tangan orang-orang suci dan para Pujangga untuk kedamaian dan kesejahteraan umat manusia. Maka didirikanlah Pura-Pura Sad Khayangan, Dang Khayangan, Khayangan Tiga, dan lain-lain.

13 Lili Rasjidi dan Ira Rasjidi, Loc.cit.

14 Lili Rasjidi dan Ira Rasjidi, Op.cit, h. 67.

15 Abdul Manan, Loc.cit.

16 Lili Rasjidi dan Ida Bagus Wyasa Putra, Loc.cit.

17 Soerjono Soekanto I, Loc.cit. 
Tempat-tempat suci tersebut memiliki radius kesucian yang disebut daerah kekeran dengan ukuran Apeneleng Apenimpug, dan Apenyengker.

Tempat suci dan kawasan suci dalam konsep Hindu memiliki definisi dan kriteria spesifik. Kawasan Suci menurut Bhisama Parisada Hindu Dharma Indonesia Pusat (PHDIP) 1994, adalah Gunung, Danau, Campuhan (pertemuan dua sungai), Pantai, Laut dan sebagainya diyakini memiliki nilai-nilai kesucian. Perlindungan terhadap kawasan suci terkait dengan perwujudan tri hita karana, yang dilandasi oleh penerapan ajaran sad kertih. Yang dimakud kawasan suci gunung adalah mencakup seluruh kawasan dengan kemiringan sekurang-kurangnya 45 derajat dilihat dari kaki lereng gunung menuju ke puncak gunung.

Dalam Penjelasan atas Perda RTRW Provinsi Bali Pasal 44 ayat (9) yang dimaksud kawasan tempat suci adalah kawasan di sekitar tempat suci/bangunan suci yang ada di Bali yang disebut Pura atau Kahyangan yang berwujud bangunan yang disakralkan sebagai tempat memuja Ida Sang Hyang Widhi Wasa, terdiri dari Kahyangan Tiga, Dang Kahyangan, Kahyangan Jagat, Sad Kahyangan dan Pura lainnya. ${ }^{18}$ Arahan peraturan zonasi radius kawasan tempat suci, berdasarkan konsep tri wana yang dipolakan kedalam 3 (tiga) zona, mencakup:

a. zona inti adalah zona utama karang kekeran sesuai dengan konsep maha wana yang diperuntukkan sebagai hutan lindung, ruang terbuka hijau, kawasan pertanian dan bangunan penunjang kegiatan keagamaan;

b. zona penyangga adalah zona madya karang kekeran yang sesuai konsep tapa wana diperuntukkan sebagai kawasan hutan, ruang terbuka hijau, kawasan budidaya pertanian, fasilitas darmasala, pasraman, dan bangunan fasilitas umum penunjang kegiatan keagamaan;

c. zona pemanfaatan adalah zona nista karang kekeran yang sesuai konsep sri wana diperuntukkan sebagai kawasan budidaya pertanian, bangunan permukiman bagi pengempon, penyungsung dan penyiwi pura, bangunan fasilitas umum penunjang kehidupan sehari-hari masyarakat setempat serta melarang semua jenis kegiatan usaha dan/atau kegiatan yang dapat menurunkan kualitas lingkungan hidup dan nilai-nilai kesucian tempat suci;

Tempat Suci (Pura) adalah eksistensi ruang dalam sebuah zonasi yang dianggap baik. Zonasi dalam tingkat kesucian Pura terbagi dalam tiga bagian yaitu jeroan, jaba tengah dan jaba atau dua bagian yaitu jeroan dan jaba. Dari sudut pandang Agama Hindu, Pura adalah tempat suci yang merupakan bagian dari kehidupan Desa Pakraman yang mempunyai tanggung jawab untuk menyelenggarakan upacara dan pemeliharaan bangunan di Pura tersebut, termasuk untuk menjaga kesuciannya, sehingga kehidupan di wilayah desa pakraman tersebut dapat terjaga dengan baik. Disinilah bentuk konkrit dari penerapan ajaran Tri Hita Karana, yang mengupayakan keharmonisan antara alam skala dan niskala, antara manusia dengan Tuhan melalui tempat persembahyangan yang disebut dengan Parhyangan, yang tidak hanya melalui Parhyangan Desa yang dikenal dengan Kahyangan Tiga tetapi juga Parhyangan lainnya

18 Herman Hidayat, dkk. (2011). Politik Ekologi. LIPI Press dan Yayasan Obor Indonesia. Jakarta, h. 119-120. 
yang merupakan Stana Tuhan dalam fungsinya yang tertentu yang berada di wilayah Desa Pakraman. ${ }^{19}$

Berdasarkan pemaparan di atas dapat disimpulkan bahwa kepentingan religi di kawasan hutan lindung Gunung Seraya, bukan hanya berupa kepentingan fisik semata tetapi mencakup kawasan suci dan kawasan tempat suci beserta dengan radius kesuciannya. Kepentingan religi berdasarkan Peraturan Pemerintah tentang Penggunaan Kawasan Hutan merupakan salah satu kegiatan dalam penggunaan kawasan hutan yang digolongkan dalam kepentingan pembangunan di luar kegiatan kehutanan yang mempunyai tujuan strategis yang tidak dapat dielakan dan menjadi salah satu kegiatan prioritas karena mempunyai pengaruh yang sangat penting secara nasional terutama terhadap bidang sosial dan budaya masyarakat, baik itu masyarakat sekitar kawasan hutan maupun masyarakat Bali pada umumnya.

\section{Kesimpulan}

Berdasarkan pemaparan di atas, dapat ditarik beberapa simpulan meliputi:

1. Kebijakan tata hutan di kawasan hutan lindung Gunung Seraya antara merupakan trade off dua kepentingan besar, yaitu di satu sisi hutan lindung merupakan kawasan hutan yang mempunyai fungsi pokok sebagai penyangga kehidupan untuk mengatur tata air, mengendalikan erosi, mencegah intrusi air laut, dan memelihara kesuburan tanah dan di sisi lain, kepentingan religi merupakan kepentingan yang bersifat strategis dan tidak dapat dielakan.

2. Pelaksanaan kebijakan tata kelola hutan di kawasan hutan lindung Gunung Seraya, terkait kebijakan dalam pengaturan penggunaan kawasan hutan untuk kepentingan religi, kenyataannya belum efektif. Hal ini disebabkan kebijakan yang ditetapkan tidak sesuai dengan hukum yang hidup dan berlaku di masyarakat khususnya masyarakat sekitar hutan. Blok khusus yang ditetapkan, hanya mengakomodir kepentingan religi secara fisik dengan batasan luas tertentu. Sedangkan kepentingan religi dalam konsep Hindu adalah meliputi Kawasan Suci (Gunung secara keseluruhan) dan kawasan tempat suci (Pura) dengan radius kesuciannya.

\section{Daftar Pustaka}

\section{$\underline{\text { Buku }}$}

Aminuddin Ilmar. (2014). Hukum Tata Pemerintahan. Prenada Media Group. Jakarta.

Dinas Kehutanan. (2009). Hutan dan Kehutanan Provinsi Bali Edisi V. Dinas Kehutanan Provinsi Bali. Denpasar.

Hidayat, Herman, dkk. (2011). Politik Ekologi : Pengelolaan Taman Nasional Era Otda. LIPI Press dan Yayasan Pustaka Obor Indonesia. Jakarta.

Nasution, Bahder Johan. (2008). Metode Penelitian Ilmu Hukum. Mandar Maju. Bandung.

19 I Gusti Ayu Agung Ariani dan Ni Nyoman Sukerti. (2014). Eksistensi Otonomi Desa Pakraman di Bali dalam Kerangka Otonomi Daerah. Jurnal Magister Hukum Udayana. 6(2), h. 14. 
Soerjono Soekanto. (1988). Efektivitas Hukum Dan Penerapan Sanksi. CV. Ramadja Karya. Bandung.

Supriyadi, Eko. (2013). Hukum Agraria Kehutanan, Aspek Hukum Pertanahan dalam Pengelolaan Hutan Negara. Raja Grafindo Persada. Jakarta.

\section{Jurnal}

Agustiono, Ariyadi dkk (2014). Kajian Perubahan Penggunaan Lahan Untuk Arahan Penataan Pola Ruang Kawasan Hutan Produksi Gedong Wani Provinsi Lampung. Majalah Ilmiah Globë, 16(1).

Ayu, I Gusti Agung Ariani dan Ni Nyoman Sukerti, (2014). Eksistensi Otonomi Desa Pakraman di Bali dalam Kerangka Otonomi Daerah. Jurnal Magister Hukum Udayana. 6(2).

Anggia, Ni Made, Paramesthi Fajar. (2015). Pelaksanaan Peraturan Daerah Provinsi Bali No 5 Tahun 2008 Tentang Pramuwisata di Kabupaten Badung. Jurnal Magister Hukum Udayana (Udayana Master Law Journal). 4(2).

Purbawiyatna, Alan dkk. (2011). Analisis Kelestarian Pengelolaan Hutan Rakyat di Kawasan Berfungsi Lindung. Jurnal Pengelolaan Sumber Daya Alam dan Lingkungan. 2(1).

\section{$\underline{\text { Hasil Pertemuan Ilmiah }}$}

Wiana, I Ketut. (2014). "Mulianya Pahala Menjaga Kelestarian Hutan", disampaikan pada Dharma Wacana tentang upaya pelestarian hutan menurut agama Hindu yang diselenggarakan oleh Dinas Kehutanan Provinsi Bali di Desa Ban, Kecamatan Kubu, Kabupaten Karangasem.

\section{Peraturan Perundang-Undangan}

Undang-Undang Dasar Negara Republik Indonesia Tahun 1945.

Undang-Undang No. 41 Tahun 1999 tentang Kehutanan, Lembaran Negara Republik Indonesia Tahun 1999, Nomor 167.

Undang-Undang No. 26 Tahun 26 Tahun 2007 tentang Penataan Ruang ,Lembaran Negara Republik Indonesia Tahun 2007, Nomor 68.

Peraturan Pemerintah No. 6 Tahun 2007 tentang Tata Hutan Penyusunan Rencana Pengelolaan Hutan serta Pemanfaatan Hutan, Lembaran Negara Republik Indonesia Tahun 2007, Nomor 22.

Peraturan Pemerintah No. 3 Tahun 2008 tentang Perubahan Atas PP. No. 6 Tahun 2007, Lembaran Negara Republik Indonesia Tahun 2008, Nomor 16.

Peraturan Pemerintah No. 45 Tahun 2004 tentang Perlindungan Hutan, Lembaran Negara Republik Indonesia Tahun 2004, Nomor 147. 
Peraturan Menteri Kehutanan No. P. 49/Menhut-II/2011 tentang Rencana Kehutanan Tingkat Nasional (RKTN) 2011-2030

Peraturan Menteri Kehutanan No. P.6/Menhut-II/2010 tentang Norma, Standar, Prosedur dan Kriteria (NSPK) Pengelolaan Hutan pada KPHL dan KPHP.

Keputusan Menteri Kehutanan Nomor : SK. 5273/Menhut-II/Reg.2-1/2014 Tentang Pengesahan Rencana Pengelolaan Hutan Jangka Panjang Kesatuan Pengelolaan Hutan Lindung (KPHL) Model Bali Timur Periode Tahun 2014-2023

Peraturan Daerah Provinsi Bali No. 3 Tahun 2001 tentang Desa Pekraman (Lembaran Daerah Provinsi Bali Nomor 29 Tahun 2001 Seri : D Nomor 29)

Peraturan Daerah Provinsi Bali No. 16 Tahun 2009 tentang Rencana Tata Ruang Wilayah Provinsi Bali Tahun 2009 - 2029, Lembaran Daerah Provinsi Bali Tahun 2009 Nomor 16. 